to a number of public schools is likely to be devised in the future. In conclusion, Mr. Latter was of opinion that nature-study might with advantage be extended to advanced biological work of the school and university laboratories.

A discussion followed, in which the chairman, Mr. Hill, Mr. Shenstone, Mr. Talbot and others took part. Prof. Armstrong said that the phrase " nature-study " was simply a "war cry" at present, and was being used by one party for something which was scientific neither in its intentions nor methods. Later on in the discussion the facts were mentioned that nature-study has a general educational significance, and is recognised in England as expressing the methods of science, but as being otherwise of an informal character.

In reply, Mr. Latter said that all he wanted was that the boys should have their eyes opened, and a resolution was passed that a subcommittee should be appointed to communicate with the preparatory schools in order to determine the form of science teaching best suited to their needs.

Wilfred Mark WebB.

\section{THE ORIGIN OF THE AUSTRALIAN MARSUPIALS.}

THE relationships of marsupials in general to other mammals, the route by which their Australasian representatives reached their present habitat, and the date of their arrival, are problems which have of late years attracted a large amount of attention on the part of naturalists, and are still far from being definitely solved. $A$ bold and vigorous attempt to determine these questions has lately been made by a promising young Canadian zoologist, Dr. B. A. Bensley, of Toronto University; who a few years ago paid a visit to England for the purpose of studying the unrivalled amount of material in the British Museum. The final results of his investigations have just been published in the Transactions of the Linnean Society of London. Needless to say, this elaborate memoir is bristling with technicalities, and much of its contents is of far too abstruse a nature to be even touched upon in a journal like our own. Nevertheless, there are certain parts of more general interest which admit of notice.

One of the difficulties which beset the study of the group has arisen from the discovery, by an Australian naturalist, that the bandicoots, unlike other marsupials, possess vestiges of a placenta, by means of which the maternal blood is brought into direct connection with that of the fœetus, and the question is whether this implies a much nearer relationship between marsupials and ordinary placental mammals than has been generally supposed to exist. Dr. Bensley answers the question in the negative, believing the bandicoot placenta to have had an independent origin. He may, of course, be right in this surmise, but it must always be remembered, as in analogous cases, that this is a summary, if convenient, way of getting rid of difficulties. Even, however, on this view, the author is of opinion that the relationship between marsupials and placentals is much more intimate than was believed to be the case by the older naturalists.

As the result of the investigations of several modern naturalists, the belief is gradually gaining ground that all the modern marsupials, with the possible exception of the Tasmanian wolf, or thylacine, are derived from a primitive arboreal type, of which the South American opossums (not the animals so miscalled in Australia) are now the only representatives. This arboreal ancestry is chiefly displayed in the structure of the foot, and even the essentially terrestrial kangaroos can be easily traced, through the phalangers (the miscalled opossums of Australia), into connection with an arboreal type. Somewhat curiously, it may be mentioned in passing, certain members of the former group - to wit, the tree-kangaroos-show a kind of reversion to the arboreal life of their ancestors. There are, however (as, indeed, would be manifestly impossible), no signs of reversion to the original grasping type of foot, tree-kangaroos hopping on the larger branches in the characteristic manner.

The opossums, then, are the most primitive of living No I786, voL. 69] marsupials, and since they date from the earlier portion (Eocene) of the Tertiary period, they are likewise the earliest animals which can be definitely included in that group, for there is great doubt whether any of the small mammals of the Secondary epoch (those, for instance, of the Stonesfield slate and Purbeck beds) are really marsupials, or at all events marsupials as we now know them.

The arboreal "radiation" (to use a term now extensively employed by American zoologists) of marsupials differentiates them from the extinct creodonts, or primitive Carnivora, of the early Tertiary epoch, which appear to have been essentially terrestrial types. Nevertheless, by means of certain Middle Tertiary South American forms (the so-called sparassodonts), these same creodonts appear to have been very closely connected with the thylacine, and thus with other marsupials, and this presumed relationship seems to have considerably puzzled Dr. Bensley. For, while including that animal in the Dasyuridæ, he suggests that it may be an altogether foreign member of the Australian fauna, and that its origin may have to be sought elsewhere-presumably in South America. He adds that no signs of arboreal ancestry are to be detected in the thylacine's foot. If this means anything, it seems to imply that the animal in question is not related at all to the typical arboreal marsupials, but that its kinship (unless the resemblances are due to " parallelism in development") is with the South American sparassodonts, and thus with the creodonts. But if so, it surely seems to follow that the creature is not, phylogenetically, a marsupial at all. The whole question seems a hopeless puzzle, and if the author cannot explain it, most surely we will not make the attempt.

To turn to less debatable ground, great interest attaches to the author's remarks concerning the huge extinct marsupial from Australia described by Owen as a carnivore, under the name of Thylacoleo. Arguing from the resemblance of its dentition to that of the phalangers, later writers, however, came to the conclusion that the creature was herbivorous. This view is discredited by Dr. Bensley, who, following Dr. Broom, reverts to the opinion that it was a flesh-eater, which, as Owen suggested, may have preyed on the contemporary giant kangaroos or even the still more gigantic diprotodons. Nevertheless, it is believed that Thylacoleo was descended from herbivorous marsupials allied to the phalangers, and, this being so, it is not easy to see why the author assigns it to a family group by itself. This, however, is but a detail.

The marsupials of Australasia, it is pointed out, must have come either from the north-west by way of the Malay Archipelago and Papua, or from the south through an Antarctic connection. Certain objections raised by Prof. Baldwin Spencer against a Malayo-Papuan route are discounted, but the author does not commit himself to any definite opinion as to the probable line of immigration.

As to the date of the immigration, the author, after mentioning that one authority makes it Jurassic, a second Cretaceous, and a third Eocene, inclines to the opinion that it did not take place until the Miocene or middle division of Tertiary time. Although we incline to the view that it was probably. Tertiary, so late an epoch as the Miocene seems to allow a very short period for the evolution of the numerous modern forms and their immediate ancestors.

Later on, it is argued that opossums may be the descendants of Jurassic ancestors, or they may themselves be the original marsupials. Assuming the latter to be the case, it may be asked, was the arboreal marsupial radiation only Tertiary, and are creodonts (inclusive of the South American sparassodonts) and the thylacine developments of an earlier common terrestrial stock related to the still earlier mammal-like reptiles?

Summing up the evidence as to the diffusion of modern marsupials, the author is of opinion that during the Oligocene period there was a radiation of opossums throughout a large portion of the northern hemisphere, and that some of these animals gained an entry into South America, where they may have given rise to the extinct Microbiotheriidæ of Patagonia. Then came the immigration into Australasia, during Miocene or Middle Tertiary time. About the same period occurred the great development of South American marsupials, such as the extinct Abderitidæ and the forerunners (Epanorthidæ) of the modern 
Cœnolestes. The sparassodonts (Prothylacinidæ) are also included in this radiation, although how these terrestrial types (which, as already stated, the author thinks were probably allied to the thylacine) were developed from arboreal forms is left unexplained. Finally, in the Pliocene occurred the irruption into South America of the modern opossums of that country.

It may be added that the author classifies modern marsupials by the foot-structure rather than by the dentition, thus making the two main groups Didactyla and Syndactyla, in place of Polyprotodontia and Diprotodontia.

R. L.

\section{CONTRIBUTIONS TO THE SCIENCE OF} $M E D I C I N E .^{1}$

THE handsome volume under notice contains a number of important papers of considerable interest to the physiologist, pathologist, and physician. It commences with a description, and an account of the opening, of the Johnston Laboratories for Biochemistry, Tropical, and Experimental Medicine, the munificent gift of Mr. William Johnston-hence the addition in the title of these reports. This has a melancholy interest also, since one of those who replied to the toasts on that occasion was the late Prof. Nocard.

The first paper is by Prof. Moore on the synthesis of fats accompanying intestinal absorption, in which it is shown that absorbed fat is re-synthesised to neutral fat in the intestinal mucous membrane. Neurology is represented by papers on the physiology of the cerebral cortex in anthropoid apes, by Dr. A. S. Grünbaum and Prof. Sherrington (reprinted from the Proceedings of the Royal Society, London), and on the electric conductivity of mammalian nerve, by Dr. Woodworth. Prof. Sherrington records a number of experiments carried out for the special chloroform committee of the British Medical Association on the dosage of the mammalian heart by chloroform; these have already been referred to in the columns of NATURE. Dr. Hume publishes a method for the isolation of the typhoid bacillus, based upon the greater motility of this organism compared with that of the colon bacillus, with which it is generally associated, so that the former will reach the surface of a column of viscid medium sooner than the latter when the two are introduced at the bottom. Mr. Roaf contributes a note on the influences of fiour and allied substances upon the typhoid bacillus, from which it would seem that emulsions of flour are inhibitory to the growth of this microbe. Dr. J. W. Stephens describes a modification of the Van Ermengem method for flagella staining.

The study of cancer is represented by two important papers, one by Dr. Prowse on the relation of vesicular mole to chorion carcinoma, the other by Mr. Keith Monsarrat on an organism associated with mammary carcinoma. In the last-named it is claimed that by the use of a special culture medium, round encapsuled organisms have been cultivated, the cultures in certain instances producing nodules of growth when inoculated into guinea-pigs.

The vitality of the Liverpool School of Tropical Medicine is evidenced by several contributions. Prof. Ronald Ross describes his "thick film" process for the detection of malaria and other parasites in blood. Dr. Christy and Dr. Stephens contribute papers on "tick fever" and on "blackwater fever" respectively, and Drs. Stephens and Christophers give a summary of researches on native malaria and blackwater fever, and suggestions for the prevention of these dread scourges.

Finally, the volume concludes with the report of the malaria expedition to the Gambia in 1902, by Mr. Dutton, to which an appendix is contributed by $\mathrm{Mr}$. Theobald on the mosquitoes collected in that expedition, with a description of some new species. Every paper contains the results of original work or observations of value, and the general "get up" of the volume is all that could be desired, the illustrations being numerous and excellent.

R. T. HeweETr.

1 "The Thompson-Yates and Johnst on Laboratories Reports." Vol. $v$ (New Series.) Part I. (London: Longmans, Green and Co., 1903.) NO. I 786 , vOL. 69]
UNIVERSITY AND EDUCATIONAL INTELLIGENCE.

Cambridge. - It is proposed to " affiliate" the University of King's College, Nova Scotia. Graduates in arts of that university will be admitted to the privileges of alfiliated students, namely, exemption from the previous examination and permission to proceed to the B.A. degree after six terms' residence in Cambridge.

An annual prize in civil engineering, of the value of about I $5 l$. has been founded by Mrs. Wimbolt, in memory of her late husband, Mr. J. S. Wimbolt, M.A., of Trinity College. The prize is open to Bachelors of Arts, and will be given for the best exercise or dissertation embodying the results of independent research in some subject related to the profession of a civil engineer.

THE Finance Committee of the Liverpool Corporation has decided to recommend the city council to grant to the Liverpool University 10,00ol. during the year 1904, such sum to be paid out of the city rate.

At the Northampton Institute, Clerkenwell, on Friday, February 26, Lord Kelvin will present the certificates and prizes on the occasion of the annual prize distribution and conversazione of members and students.

A CONFERENCE on nature-study, arranged by the School Nature Study Union, will be held on Saturday, January 30 , at the Passmore Edwards' Settlement, Tavistock Place, W.C. The chair will be taken by Mr. Cyril Jackson, Chief Inspector, Board of Education, and two short papers will be read by representatives of elementary and secondary schools.

\section{SOCIETIES AND ACADEMIES. LONDON.}

Royal Society, December 10, I903.- "On the Resemblances Exhibited between the Cells of Malignant Growths in Man and those of Normal Reproductive Tissues." By J. Bretland Farmer, J. E. S. Moore, and C. E. Walker.

The object of the communication is to direct attention to certain important cytological transformations exhibited during the development of malignant growths in man. The changes described appear to be diagnostic of malignant as opposed to benign growths, inasmuch as they seem to be absent from the latter class of tumours. Briefly, the authors have identified, within the proliferating edges of advancing growths, cells that exhibit a type of karyokinesis presenting an extraordinary similarity to, if not identity with, the heterotype mitosis that forms so constant a character during the production of sexual cells. This mitosis, or nuclear division, is remarkably different in character from the other divisions in the body-cells, and is recognised with ease and certainty. The nuclear chromasomes pass through a totally different series of changes as compared with those exhibited by the chromosomes of ordinary nuclei. Not only in shape is this difference manifested, but also in the reduction of their number to onehalf; and in all the subsequent cell generations that follow from a cell that has once passed through the heterotype mitosis the reduced number of chromosomes is retained in normal cases that lead to the direct formation of the sexual cells themselves. In any cells, otherwise of similar (heterotype) origin, that are not about to form actual sexual cells, variations and abnormalities may supervene.

All the principal varieties that are commonly met with during the evolution of the sexual cells have been identified in malignant growths of carcinomatous and sarcomatous types. The authors consider themselves justified in relating the malignancy of the growth with these facts, and they regard the malignant tissue in question as having originated in cells that have lost their somatic character, and have directly assumed the, nature of reproductive tissues.

They propose the term gametogenic to signify tissues that are potentially or actually about to give rise to sexual cells (gametes), whilst they call the cells that have passed through the metamorphoses indicated above, but which do not finally form functional gametes, gametoid. This expression is thus intended to embody their conclusion that the 